\title{
Bazı Bacillus thuringiensis (Berliner) (Bacillales: Bacillaceae) İzolatlarının Yponomeuta malinellus Zell. (Lepidoptera: Yponomeutidae) ve Cydia pomonella L. (Lepidoptera: Tortricidae) Larvaları Üzerine İnsekdisidal Etkileri
}

\author{
Ömer ERTÜRK ${ }^{1 *}$ \\ ${ }^{1}$ Ordu Üniversitesi Fen Edebiyat Fakültesi Biyoloji Bölümü, ORDU \\ *Sorumlu yazar: oseerturk@hotmail.com
}

Öz

Bu çalışmada, elma ağaçları ve diğer bitkilerin, ortak zararlılarına daha etkili ve güvenli bir biyolojik mücadele ajanı bulmak için Yponomeuta malinellus Zell.(Lepidoptera:Yponomeutidae) ve Cydia pomonella L.(Lepidoptera: Tortricidae)'ye karşı bazı Bacillus thuringiensis biyolojik izolatlarının insektisidal etkileri araştırılmıştır. Y.malinellus larvalarının ölüm oranları, toksin HD-1 ile $0.97 \pm 0.03 \mathrm{~A}$, toksin BTS-1 ile $0.83 \pm 0.03 \mathrm{~A}$, Bacillus thuringiensis Berliner ile $0.67 \pm 0.03 \mathrm{~B}$ ve Bacillus thuringiensis subsp.kurstaki ile $0.67 \pm 0.03 B$ olarak tespit edilmiştir. C.pomonella larvaları ölüm oranları toksin HD-1 ile $0.67 \pm 0.03 \mathrm{Ab}$, toksin BTS-1 ile $0.57 \pm 0.03 \mathrm{Ab}$, Bacillus thuringiensis Berliner $0.53 \pm 0.03 \mathrm{~A}$ ve Bacillus thuringiensis subsp.kurstaki ile $0.53 \pm 0.03 \mathrm{~A}$ olmuştur.

Anahtar Kelimeler: Bacillus thuringiensis; Yponomeuta malinellus; Cydia pomonella; Biyolojik kontrol

Insecticidal Effects of Some Bacillus thuringiensis (Berliner) (Bacillales: Bacillaceae) Isolates on the Larvae of Yponomeuta malinellus Zell. (Lepidoptera: Yponomeutidae) and Cydia pomonella L. (Lepidoptera: Tortricidae)

\begin{abstract}
In the present study, in order to find a more effective and safe biological control agent against common pests of apple trees and other plants, we tested the insecticidal effects of some Bacillus thuringiensis biological agents against Yponomeuta malinellus Zell. (Lepidoptera: Yponomeutidae) and Cydia pomonella L. (Lepidoptera: Tortricidae). Treatment mortality of larvae of $Y$. malinellus, was $0.97 \pm 0.03 \mathrm{~A}$ with toxin HD-1, $0.83 \pm 0.03 \mathrm{~A}$ with toxin BTS-1, 0.67 $\pm 0.03 \mathrm{~B}$ with Bacillus thuringiensis Berliner and $0.67 \pm 0.03 \mathrm{~B}$ with Bacillus thuringiensis subsp. kurstaki. Treatment mortality of larvae of $C$. pomonella was $0.67 \pm 0.03 \mathrm{Ab}$ with toxin HD-1, $0.57 \pm 0.03 \mathrm{Ab}$ with toxin BTS- $1,0.53 \pm 0.03 \mathrm{~A}$ with Bacillus thuringiensis Berliner and $0.53 \pm 0.03 \mathrm{~A}$ Bacillus thuringiensis subsp. kurstaki.
\end{abstract}

Keywords: Bacillus thuringiensis, Yponomeuta malinellus, Cydia pomonella, biological control 


\section{Giriş}

Hızla artan dünya nüfusunun gıda ve giyim ihtiyaçlarını karşılayabilmek için birim sahadan fazla verim alma uygulamalarının başında bitkilerin zararlı böceklerden korunması gelmektedir. Günümüzde bitkilerin korunması daha çok kimyasal ilaçlar kullanılarak yapılmaktadır. Kimyasal ilaçlar kullanılırken, bunların birçok yan etkileri ortaya çıkmaktadır. Zirai mücadele ilaçlarından bugün için vazgeçilememesinin nedeni, bu ilaçlara alternatif bir mücadele yönteminin tam anlamıla geliştirilememesidir. Kimyasal mücadelenin dışındaki mücadele metotlarının yeteri kadar geliştirilememesinden ve geliştirilen metotların zararlı, pahalı ve etkisiz olmasından dolayı zirai mücadele ilaçlarının uygulanmasının daha uzun yıllar devam edeceği düşünülmektedir. Biyolojik mücadele, zararlı böceklerin yapmış olduğu zararları en aza indirmek için bu böceklere karşı doğal düşmanlarını kullanma olarak tanımlanabilir. Doğal düşman terimi, parazitler ve predatörlerle birlikte hastalık oluşturan mikroorganizma ve diğer organizmaları kapsamaktadır. Ancak, hastalık yapan organizmaların kullanımı, genellikle mikrobiyal mücadele olarak adlandırılır (Peter, 1984). Mikrobiyal mücadelenin büyük bir avantajı kimyasal mücadele yöntemleriyle bağlantılı birçok problemi ortadan kaldırmasıdır (Ecevit, 1988). Zararlı böceklerle mücadelede mikrobiyal etmenlerin kullanımı ilk olarak 18. yüzyılda kaydedilmiştir. Metarrhizium anisopliae (Metch.) şeker pancarına zarar veren Cleonus punctiventris türüne karşı kullanılmıştır (National Reserch, Council 1984).

Ülkemizde üretilen meyveler arasında elma, gerek ağaç sayısı gerekse elde edilen ürün miktarı bakımından ekonomik öneme sahip en önemli meyvelerden biridir. Yumuşak çekirdekli ağaçlar arsında 2007 verilerine göre 47.196 adet elma ağacı mevcuttur ve 38.328 adedi meyve vermektedir. Ağaç başı verim $65.3 \mathrm{~kg} /$ ağaç olmak üzere yıllık üretim 2.457 bin ton üretim miktarıyla ilk sırada yer alır. Yumuşak çekirdekli ağaçlar arasında 2015 verilerine göre 70.696 adet elma ağacı mevcuttur ve 18424 adedi meyve vermektedir. Ağaç başı verim $49.1 \mathrm{~kg} /$ ağaç olmak üzere yıllık üretim 2.569 bin ton üretim olduğu tespit edilmiş bu verilerin bunu takip eden yıllarda Türkiye Gıda, Tarım ve Hayvancılık Bakanlığı (GTHB)'nın verilerine göre 1998-2015 yıllarında yumuşak çekirdekli meyvelerin miktarlarında önemli bir değişme görülmemiştir. Gerek ağaç sayısı bakımından gerekse meyve miktarı bakımından elma meyvesinin ne kadar önemli olduğu, ülke ekonomisine kazandırdığı gelir açıkça görülmektedir (Anonim, 2015). Bütün tarım ürünlerinde olduğu gibi elma üretimi yapılan elma bahçelerinde elma ağaçlarına zarar veren çeşitli zararlı böcek türleri vardır ve bu zararlılar oldukça büyük ekonomik kayıplara sebep olmaktadır (TÜik,2007-2015). Elma ağ kurdu (Yponomeuta malinellus Zell. (Lep.:Yponomeutidae) ekonomik olarak önemli bir zararlıdır. Elma ağaçlarının yaprak ve genç sürgünlerinden oburca beslenerek zarar yapan larvalar ekonomik olarak büyük kayıplara neden olmaktadırlar. Elma iç kurdu (Cydia pomonella L. (Lepidoptera: Tortricidae), başta elma olmak üzere armut, ayva, ceviz ağaçlarının en önemli zararlısıdır. Doğrudan meyvelerde zarar yapan larvalar, meyveleri delerek içlerinde galeriler açmakta, etli kısmını ve çekirdek evini yiyerek pislikler bırakmaktadır. Bütün bunların sonucu olarak meyvelerin dökülmesine, ağaçta kalabilen kurtlu meyvelerin ise niteliğinin bozulmasına ve dolayısıyla elmanın piyasadaki değerinin 
düşmesine neden olmaktadır. Elma iç kurdu özellikle Nisan mayıs aylarında olgunlaşmamış elmaları delerek zararını oluşturmakladır. Elmalarda zararlı tür sayısının fazla olması ilaçlama sayısını ve kullanılan ilaç sayısını artırmakta, bu nedenle üretim maliyeti yükselirken, çevre sağlığı bakımından olumsuz etkiler ortaya çıkmaktadır. Söz konusu olan bu sebeplerden dolayı özellikle elma üretiminde önemli yer alan birçok ülkede çok sayıda araştırıcı entegre mücadele sisteminin elma üretim alanlarında uygulanabilmesi için çalışmaktadır (Gottwald ve ark., 1986; Driesche ve Carey , 1987; Anonymous, 1991). Ülkemizde bugüne kadar yapılan entegre mücadele sistemi uygulamaları başlangıç çalışmaları niteliğindedir (Giray 1969, Erdem 1979; Yiğit ve Uygun 1982; Kıroğluve ark., 1984; Çiftçi ve ark., 1985; Gürses ve ark., 1985). Elma bahçelerinde bulunan zararlı türler ile onların doğal düşmanları adlı bir çalışmanın sonucunda 38 zararlı tür tespit edilmiş ve bu türlerin aralarında 15 türün Lepidoptera takımına, 7 türün Homoptera, 6 türün Coleoptera, ayrıca 1'er türünün Heteroptera ve Isoptera takımlarında olduğu tespit edilmiştir (Giray 1969; Erdem 1979; Yiğit ve Uygun 1982; Kıroğluve ark., 1984; Çiftçi ve ark., 1985; Gürses ve ark., 1985). Ayrıca Gıda, Tarım ve Hayvancilık Bakanlığı'nın 2010 yııında elma hastalık ve zararlıları ile ilgili (el kitabı şeklinde) yaptığı bir yayın da elma hastalık ve zararılıarı el kitabında bunu destekler niteliktedir(T.C. Gıda, Tarım ve Hayvancılık Bakanlığı Elma ağaçlarında ekonomik zarar eşiğini aşan ve ekonomik öneme sahip olan türler $C$. pomonella ve $Y$. malinellus Zell (Peter, 1984)'dir. Elma ağ kurdu (Yponomeuta malinellus Zell. (Lep.:Yponomeutidae) ekonomik olarak önemli bir zararlıdır. Elma ağaçlarının yaprak ve genç sürgünlerinde oburca beslenerek zarar yapan larvaları ekonomik olarak büyük kayıplara neden olmaktadırlar. Lepidoptera takımına ait olan bu elma zararlılarının ülkemizde elma üretimi yapılan bütün bölgelerde ekonomik zarar eşiklerini aşarak önemli ürün kayıplarına neden oldukları bazı araştırmacılar tarafından bildirilmektedir (Giray, 1969; Erdem, 1979; Yiğit ve Uygun, 1982; Kıroğlu ve ark., 1984; Çiftçi ve ark., 1985; Gürses ve ark., 1985). İren ve Ahmed (1973), tarafından yapılan bir başka çalışmada Türkiye'de elma zararlılarının sayısının 80 olduğu bildirilmiştir. Kıroğlu ve ark., (1984), Karadeniz Bölgesindeki elma bahçelerinde \%50 si zararlı toplam 204 tür tespit etmişlerdir. Gürses ve ark., (1985), Marmara Bölgesinde 145 'i zararlı olmak üzere toplam 190 tür toplamışlardır. Adana, i̇çel ve Kahramanmaraş'ta Yiğit ve Uygun (1982), 38'i zararlı 132 tür belirlemişlerdir.

Elma iç kurdu ve elma ağ kurdu ile mücadele günümüzde kısmen kimyasal kısmende biyolojik bazı preparatlarla yapılmakta iken ve geçmişte ise kimyasal insektisidler ile yapılmaktadır. Bu insektisitler hem pahalıdırlar hem de ekolojik çevreyi olumsuz bir şekilde etkilemektedirler (Ecevit, 1988). Bu zararlılarla mücadelede kullanılan insektisitlerin hepsinin ortak özelliği bal arılarını ve balıkları etkilemeleridir. Özellikle Karadeniz Bölgesi'nin önemli gelir kaynaklarının arıcılık ve balıkçılık olduğu düşünülürse, bu zararlı ile mücadelede kullanılan insektisitlerin bölgeye yapmış olduğu zarar daha iyi anlaşımaktadır (Tiryaki, 2010).

Elma iç kurdunun ve elma ağ kurdunun mikrobiyal mücadelesinde kullanılabilecek ruhsatlı biyolojik mücadele etmeni sınırlı şekildedir. Zararlının mücadelesinde biyopreparatlardan (Bacillus thuringiensis) başarılı bir şekilde kullanılmaktadır ( Anonim, 2010). Bununla birlikte Avrupa ülkelerinde Fransa, Yugoslavya, İtalya, Bulgaristan ve 
Amerika'da yapılan çalışmalarda $C$. Pomonella'nın larva parazitlerinden Hyssopus pallidus (Hymentera)'nun biyolojik mücadele etmeni olarak C. Pomonella larvalarını belirli düzeyde tuttuğunu ve tarım alanlarında kullanıldığı belirtilmiştir (Silvia, 2001). Kanada' da bazı tarım alanlarında Granulosis virus (CpGV) elma iç kurduna karşı denenmiş ve etkili bulunmuştur (Jaques ve ark., 1994).

Elma ağ kurdu ile çok fazla biyolojik mücadele çalışmaları yapıldığı halde şu ana kadar etkili sayıda biyolojik ajan geliştirilememiştir. Sadece bir kaç bilim adamı bu zararlının parazitleri ve patojenleri hakkında çalışmalar yapmıştır (Tiryaki, 2010). Türkiye'de sadece Bacillus thuringiensis, $16000 \mathrm{IU} / \mathrm{mg}$ olarak kullanılmaktadır. Bununla birlikte dünyanın bazı ülkelerinde bazı bilim adamları elma ağkurdunun doğal düşmanlarını (parazitlerini ) tarım alanlarında elma ağkurduna karşı biyolojik ajan olarak kullanmışlardır (Franck ve Genevieve, 1997). $\mathrm{Bu}$ araştırıcılar Diadegma armillata (Hymenoptera: Ichneumonidae) adlı elma ağ kurdu parazitini $Y$. malinellus ve $Y$. cagnagellus'e karşı kullanmışlar ve etkili olduğunu belirtmişlerdir. Junnikala (1960) ve Dijkerman (1987), yaptıkları çalışmalar da Diadegma armillata'nın Y. malinellus'un larva ve pupalarına saldırarak önemli kayıplar verdiğini belirtmişlerdir. Kuhlmann ve ark.,. (1998; Dijerman, 1987 ), Ageniaspis fuscicollis (Hymenoptera: Encyrtidae) yumurta-larva parazitinin $Y$. malinellus yumurtalarına saldırdığı ve büyük ölçüde yumurta açılımını önlediğini bildirmişlerdir (Kuhlmann ve ark., 1998). Kimyasal insektisitlerin yan etkilerinin iyice anlaşılması bilim adamlarını daha etkili ve daha güvenli bir mücadele ajanı bulmaya yöneltmiştir. Tarım sektöründe büyük ekonomik zararlara neden olan elma iç kurdu ve elma ağ kurdu (Peter, 1984) ile mücadelede daha etkili ve daha güvenli bir mücadele ajanı bulmak kaçınılmaz olmuştur. Türkiye tarım alanlarının \%6'sı meyve-zeytinbağ alanı olarak değerlendirilmektedir ve Dünyanın önemli meyve üreticisi ülkelerinden olanTürkiye ise 2.5 milyon tonla Dünyada dördüncü sırada yer almaktadır (Oğuz, 2009). Türkiye, dünya üzerinde bulunduğu coğrafi konumu nedeniyle tropik bahçe bitkileri dışında tüm meyve türleri için oldukça elverişli bir iklime sahiptir. Bu bakımdan Türkiye, bahçe bitkileri kültürünün doğuş yeri, dünyada yetişen birçok meyve türünün ana vatanı konumundadır (Ağaoğlu ve ark., 1997). Türkiye elmanın anavatanı sınırları içerisinde yer almaktadır. Bu durum Türkiye'ye üretim açısından avantaj sağlamaktadır. Türkiye'de en fazla yetiştirilen meyve türlerinden biri olan elmanın yapılan araştırmalar sonucunda sağlık ve beslenme açısından faydalarının ortaya konulmuş olması tüketimini teşvik etmektedir. Taze olarak tüketilebilen elma, kurutulmuş elma, meyve suyu, sirke, marmelat, tatlı, şarap, esans, kozmetik gibi pek çok ürünün üretiminde de kullanılmaktadır. Bu çalışmada literatürde bulunan bazı biyolojik mücadele etmenlerinin bu zararlılar üzerine insektisidal etkilerinin araştırılması amaçlanmıştır.

\section{Materyal ve Metot}

\section{Larvaların toplanması}

$\mathrm{Bu}$ çalışma boyunca gerekli olan ve farklı yerlerden toplanan larvalar toplandıkları yer, bulundukları bitki ve tarih yazıldıktan sonra farklı özel kaplara konularak laboratuvara getirilmiştir. C. pomonella 2000 ve 2001 yılları Haziran ve Temmuz aylarında Amasya, Ordu, Trabzon, Kayseri ve Gümüşhane il ve ilçelerinden toplanmıştır. Çalışma alanı olarak seçilen elma bahçelerinde elma ağaçlarında enfekte olmuş meyveler elma iç kurdunun yaptığı enfeksiyondan dolayı rahatlıkla tanıyor ve ağaçda yapılan silkelemeyle delik 
meyveler yere düşüyor. Bu elmaları ortadan yardığımızda elmaların orta kısmında bezya ve pembemsi olarak olgun larvaları toplayabiliyorsunuz. Toplanan larvalar makroskopik incelemeleri yapılarak ölü, hastalıkı ve yavaş hareket edenler olarak ayrılmıştır. Diğerleri ise aynı evreler bir kapta olacak şekilde $25 \mathrm{~cm}$ çapında ve $30 \mathrm{~cm}$ derinliğindeki kafeslere konularak doğal besinleri olan elma ile beslenmiştir. Aynı şekilde $Y$. malinellus'un değişik evrelerdeki larvaları 2000 ve 2001 yıllarının Nisan, Mayıs ve Haziran ayları boyunca Amasya, Ordu, Tokat ili ve ilçelerinden, elma ve mahlep ağaçlarından, yaprak ve sürgünler üzerinden toplanmıştır. Toplanan $Y$. malinellus larvalarının. makroskobik incelemeleri yapılarak larvalar ölü, hastalıklı ve yavaş hareket edenler olarak ayrılmıştır. Diğerleri ise aynı evreler bir kapta olacak şekilde $25 \mathrm{~cm}$ çapında ve $30 \mathrm{~cm}$ derinliğindeki kafeslere konularak doğal besinleri olan elma ve mahlep yaprakları ile beslenmiştir.

Cydia pomonella ve Yponomeuta malinellus'a karşı çeşitli biyolojik ajanların hazırlanması ve insektisidal etkilerinin belirlenmesi

Bacillus thuringiensis toksinlerinin hazırlanması: Çalışmada denenen iki toksin Bacillus thuringiensis'in 1.Harry Dumagae strain (HD-1) ve tenebrionis strain 2. (BTS-1) suşlarından izole edilmiş toksinlerdir. ; 3. $B$. thuringiensis Berliner; 4. B. Thuringiensis $\mathrm{Bu}$ toksinlerden $0.005 \mathrm{gr}$ alınmıştır ve $5 \mathrm{ml}$ fosfat tampon solüsyonu (PBS) içerisinde çözülmüştür. Bu çözeltiden $1 \mathrm{ml}$ alınmış ve besin üzerine püskürtülmüştür. Spor oluşturan numuneler 72 saat $32{ }^{\circ} \mathrm{C}$ inkübasyondan sonra yoğunluğu $1.8 \times 10^{9}$ bakteri/ml olacak şekilde ayarlanmıştır. Bacillus thuringiensis toksinlerinin bakteri tarfından üretilen bir gen ürünüdür ve üretilen bakterinden böcek üzerinde daha etkilidir. Biyolojik mücadelede kullanılan bu bakteriler böceği öldürmeleri ancak onlara bir bulaşma sonucunda olur ve böcek içine giren bakteri önce bu toksini üretmesi gerekir, fakat bakteri gen ürünü olan toksik direkt verildiği zaman kısa sürede etki oluyor ve çevre şartlarından da etkilenmiyor. (Lipa, 1975; by Moar ve ark..,1995). (Bu Numuneler KTÜ Biyoloji Bölümünde Prof DR. Zihni DEMIRBAĞIN LAB.'dan Temin edilmiştir).

C. pomonella ve Yponomeuta malinellus larvalarına karşı biyolojik numunelerin insektisidal etkileri

Insektisidal etkilerin belirlenmesinde 5 farklı biyolojik ajan kullanılmıştır. 4 grup biyolojik ajanı denemek için, 2 grubu kontrol olmak üzere 7 tane deney grubu oluşturulmuş ve her gruba ilgili zararlının dönem larvalarından 10 tane olacak şekilde hazırlık yapılmıştır. Denemelerde temiz petriler kullanılmıştır. Bu petrilerin tabanına daha önceden hazırlanmış diyet besiyer yaklaşık olarak $1 \mathrm{~cm}$ kalınlığında yerleştirilmiştir. Daha sonra diyet besi yeri üzerine laboratuvarda hazırlanmış biyolojik ajanlardan belirlenen oranlarda 1ml püskürtülmüştür (Lipa, 1975). Biraz kurutulduktan sonra her petriye doğadan toplanmış içerisinde C. pomonella larvalarından 10'ar tane bulunduğu tahmin edilen elmalardan çıkarılan ikinci-üçüncü instar C. pomonella larvaları bırakılmıştır. İki kontrol grubundan biri üzerine su püskürtülürken diğerine de numunelerin çözüldüğü PBS püskürtülmüştür. Daha sonra petrilerin ağzı hava alacak şekilde kapatılmıştır. Bütün deney grupları $26 \pm 2^{\circ} \mathrm{C}^{\prime}$ de ve $\% 60$ nem içeren iklim dolabına 12:12 ışık periyodunda bırakılmış ayrıca her 24 saatte kontrolleri yapılmış ve ölen larvalar çıkartılmıştır (Ben-Dov et al., 1995). Bu tür çalışmalarda genel olarak biyolojik ajanın durumuna göre en fazla sekiz gün boyunca 
devam ettirilir ve deney sonlandırılır. Bu süre zarfında biyolojik ajan etkili ise ölümler gerçekleşir. Bizde çalışmamızda sekiz gün boyunca ölümlerin olduğunu tespit etetik ve işlemlerimizi bu sonuçlara göre değerlendirdik.

\section{istatiksel analiz}

Kolmogorov-Smirnov ve Levene'nin testleri, sırasıyla, varyans normalliğini ve homojenliğini test etmek için kullanılmıştır. Veri kümeleri Tukey çoklu karşılaştırma testi ile karşılaştırıldığında, iki-yönlü ANOVA ve araçlar ile analiz edilmiştir. Tukey testi sonuçları harfle ifade edilmiştir/gösterilmiştir. Değişkenler ortalama (SEM) ortalama \pm standart hata olarak sergilendi gösterilmiştir. Alfa düzeyi \% 5 olarak belirlenmiştir. İstatistiksel analizler Minitab 17 istatistik paket programı kullanılarak yapılmıştır.

\section{Araştırma Bulguları ve Tartışma}

Kontrol grubu olarak suyun bulunduğu petride hiç ölüm olmamıştır. Diğer yandan $Y$. malinellus larvalarının ölüm oranları, toksin HD-1 ile 0.97 $\pm 0.03 \mathrm{Aa}$, toksin BTS- 1 ile $0.83 \pm 0.03 \mathrm{Aa}$, Bacillus thuringiensis Berliner ile $0.67 \pm 0.03 \mathrm{Ba}$ ve Bacillus thuringiensis subsp. kurstaki ile $0.67 \pm 0.03 \mathrm{Ba}$ olarak belirlenmiştir (Şekil 1, Çizelge 1).

Bu böcek biyolojisi gereği ağ oluşturduğu için, bu ajandan etkilenen larvaların petriler içinde, genellikle bazılarının baş tarafından bazılarının arka kısımdan olmak üzere ağdan asıldıkları, iştahsız oldukları ve yavaş hareket ettikleri, sağlıklı larvalara göre renklerinin biraz daha koyu olduğu ve ölü larvaların vücutlarının sıvımsı bir hal aldığı belirlenmiştir. Bakteri enfeksiyonuna maruz kalan larvaların evre durumu da bu enfeksiyonun derecesini etkilemektedir. Larva dönemi ilerledikçe diğer bir ifadeyle larva büyüdükçe enfeksiyon etkisinin azaldığı tespit edilmiştir. Sağlıklı larvaların ise beslenmeden sonra bir araya gelerek gruplar oluşturdukları gözlenmiştir. Kontrol grubu olarak suyun bulunduğu petride hiç ölüm olmamıştır. Larva evresi yani instar durumu ilerledikçe larvaların biyolojik ajanlardan enfeksiyonunun azaldığı tam tersi olarakta instar durumu azaldıkça enfeksiyonun etkili olduğu tespit edilmiştir. Sağlıklı larvaların ise beslenmeden sonra bir araya gelerek gruplar oluşturdukları gözlenmiştir. Kontrol grubu olarak suyun bulunduğu kapta hiç ölüm olmamıştır.

Sonuç olarak, C. pomonella larvalarına karşı/larvaları üzerinde uygulanan 4 farklı biyolojik ajanın etkilerine baktı̆ı̆ızda $B$. thuringiensis'in Harry Dumagae suşundan izole edilmiş olan toksin (HD-1) toksininin ekonomik olarak büyük zararlar veren bu böceğin larvaları ile biyolojik mücadelede etkili bir şekilde kullanılabileceği görülmüştür. Yapılan varyans analizi sonucunda zararlı toksin interaksiyonu istatistik olarak önemli bulunmuştur $(p<0.05)$. Buna uygun olarak yapılan Tukey testi sonuçları Çizelge 1 'de harfli gösterim şeklinde verilmiştir.

Çalışmanın diğer bir kısmını oluşturan $Y$. malinellus'a karşı denenen biyolojik ajanların test sonucunda bu larvaya en büyük etkiyi HD1 toksinine (Bacillus thuringiensis'in Harry Dumagae suşundan $0.97 \pm 0.03 \mathrm{Aa}$ ) göstermiştir. Diğer yandan BTS-1 toksini $(0.83 \pm 0.03 \mathrm{~A}) \mathrm{HD}-1$ 'e oranla daha düşük bir etki, göstermiştir Bacillus thuringiensis Berliner ve Bacillus thuringiensis var. kurstaki $0.67 \pm 0.03 B$ ile aynı etkiyi göstermişlerdir (Cappuccino ve Sherman, 1992). Sezen ve Demirbağ, (1999), izole ettikleri Serratia marcescens \%92'lik bir etki göstermiştir. Bacillus thuringiensis Berliner 0.67 $\pm 0.03 \mathrm{Ba}$, Bacillus thuringiensis var. kurstaki $0.67 \pm 0.03 B a a^{\prime}$ lik bir etki göstermiştir. 
Bir başka çalışmada Bacillus thuringiensis suşlarının çeşitli böcek türleri üzerinde etkili olduğu bulunmuştur. (Ertürk2007). Ayrıca Lipa, (1972) HD-1 ve BTS-1 toksik gen ürünlerinin Euproctis chrysorrhoe larvalarına karşı çok etkili olduğunu bildirmiştir. Diğer taraftan HD-1 ve BTS-1Gypsonoma dealbana ve Hyphantria cunea larvaları üzerinde yüksek bir etki gösterdiği bildirilmiştir (Demir ve ark, 2000). Başka bir araştırmacı bu biyolojik ajanların Balaninus nucum ve Euproctis chrysorrhoea böcekleri üzerinde etkili olduğunu bulmuştur (Yaman ve ark., 1999).

Çizelge 1. Tukey ve istatiksel test sonuçları

Table 1. Tukey and statistical test results

\begin{tabular}{lllccc}
\hline $\begin{array}{l}\text { Zararlı } \\
\text { Pest }\end{array}$ & $\begin{array}{l}\text { Toksin } \\
\text { Toxin }\end{array}$ & $\begin{array}{l}\text { Uygulama } \\
\text { Application }\end{array}$ & Mean \pm SEMean & $\begin{array}{c}\text { Standard Sapma } \\
\text { Standard deviation }\end{array}$ & Min-Max \\
\hline C. pomonella & HD-1 & 3 & $0.67 \pm 0.03 \mathrm{Ab}$ & 0.058 & $0.60-0.70$ \\
& BTS-1 & 3 & $0.57 \pm 0.03 \mathrm{Ab}$ & 0.058 & $0.50-0.60$ \\
& Berliner & 3 & $0.53 \pm 0.03 \mathrm{Aa}$ & 0.058 & $0.50-0.60$ \\
& Bacillus & 3 & $0.53 \pm 0.03 \mathrm{Aa}$ & 0.058 & $0.50-0.60$ \\
Y. malinellus & HD-1 & 3 & $0.97 \pm 0.03 \mathrm{Aa}$ & 0.058 & $0.90-1.00$ \\
& BTS-1 & 3 & $0.83 \pm 0.03 \mathrm{Aa}$ & 0.058 & $0.80-0.90$ \\
& Berliner & 3 & $0.67 \pm 0.03 \mathrm{Ba}$ & 0.058 & $0.60-0.70$ \\
& & & $0.67 \pm 0.03 \mathrm{Ba}$ & 0.058 & $0.60-0.70$ \\
\hline
\end{tabular}

Bakteri ve bakteriyel toksinlerin Aynı zararlı üzerine hem toksinde hem de zararlı açısından, önemlilik ve farklılığı (Tukey testi, $p$ $<0.05)$ aralığında

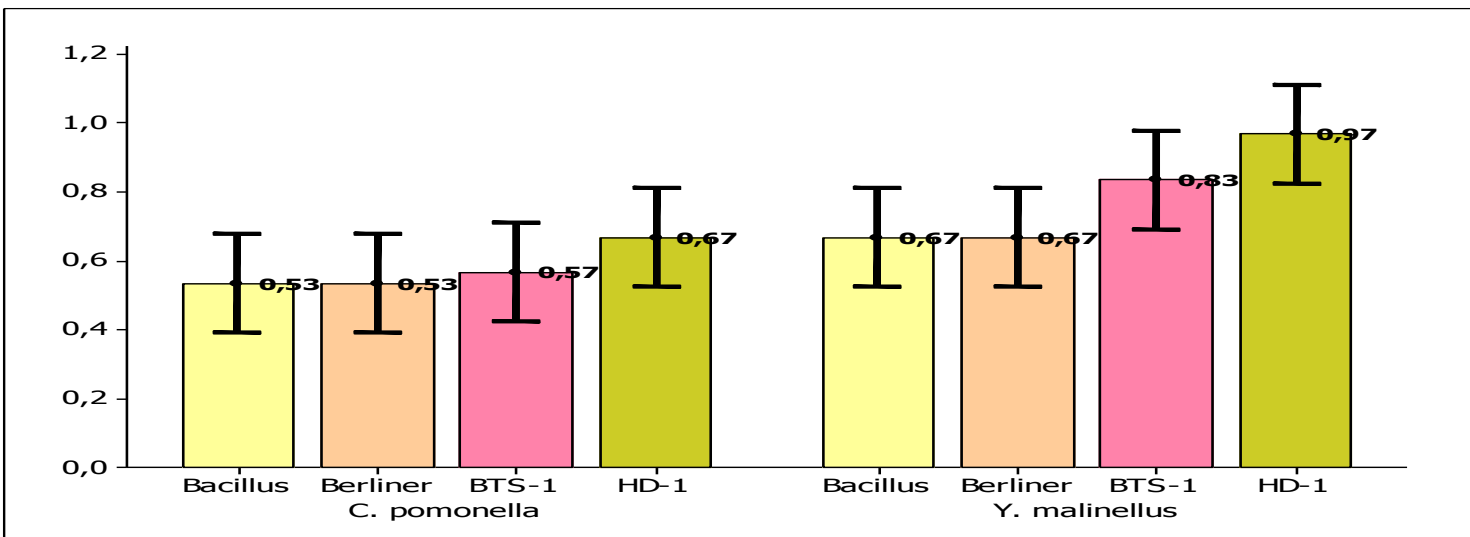

Şekil 1. B. thuringiensis'nin biyolojik ajanlarının Y. malinellus, ve C. pomonella üzerindeki yaklaşık

1 haftalık insektisidal \% 95 güven aralıkları (\% $95 \mathrm{Cl}$ ) ile mortalite oranı ortalamaları

Figure 1. Insecticidal effects of $B$. thuringiensis biological agents on/against $Y$. malinellus and $C$. pomonella about 1 week. 95\% confidence intervals $(95 \% \mathrm{Cl})$ with an average mortality of rate 


\section{Sonuçlar}

Sonuç olarak, uygulanan 4 farklı biyolojik ajanın etkilerine baktığımızda $B$. thuringiensis'in Harry Dumagae suşundan izole edilmiş toksin (HD-1) ve diğer ajanlar ekonomik olarak büyük zararlar veren $Y$. malinellus ile biyolojik mücadelede etkili bir şekilde kullanılabilir. Kullanılan bu biyolojik ajanların insanlar ve diğer hayvanlar üzerinde hiçbir yan etkisi yoktur. Bu toksinler ve bakterilerin etkisi alkali ortamda olmaktadır (Tayabali ve Seligy, 2000).

Bununla birlikte kullanılan kimyasallar çevredeki faydalı canlılar ve insanlar üzerinde çok büyük olumsuz etkiler yapmaktadır (Ecevit, 1988). Halbuki biyolojik mücadele uygulaması durumunda hem kimyasalların çevreye yapmış olduğu zararlar azalacak hem de mücadelede ortaya çıkan maliyet oranı düşük olacaktır. Bu çalışmasında elde edilen sonuçlar bu iki zararlı ile biyolojik mücadelede mikrobiyal ajanların kullanılabileceğini göstermektedir.

\section{Kaynaklar}

Ağaoğlu, Y.S., Çelik, H., Çelik, M., Fidan, Y., Gülşen, Y., Günay, A., Halloran, N., Köksal, A.I.., Yanmaz, R., 1997. Genel Bahçe Bitkileri. T.C. A.Ü.Z.F. Eğitim, Araştırma ve Geliştirme Vakfı Yayınları No: 4, Ankara.

Anonim, 2007:Türkiye İstatistik Kurumu. http://www.tuik.gov.tr.

Anonim, 2010. Elma Hastalık ve Zararlıları ile Mücadele T.C. Gıda, Tarım ve Hayvancılık Bakanlığı ve Köyişleri Bakanlığı Koruma ve Kontrol Genel Müdürlüğü, Ankara.

Anonim, 2015:Türkiye İstatistik Kurumu. http://www.tuik.gov.tr.

Anonymous, 1991. Integrated Pest Management for Appleand Pears. University of California Statewide Integrated Pest Management Project Division of Agriculture and Naturel Resources Publıcation, 3340, California, 214.

Ben-Dov, E., Boussiba, S., Zaritsky, A. 1995. Mosquito larvacidal activity of Escherichia coli with combinations of genes from Bacillus thuringiensis subsp. İsraelensis. Bacteriology 177 2851-2857.

Cappuccino, J. G., 1992: Sherman, N, Microbiology, a Laboratory Manual, Third Edition, Rockland Community College, Suffern, New York.

Çiftçi, K., Türkyılmaz, N., Kumaş, F., Özkan, A., 1985. Antalya Illi Elma Bahçelerindeki Önemli Zararlılar ille Doğal Düşmanlarının Tespiti Üzerinde Ön Çalışmalar, Bitki Koruma Bülteni, 25(1-2): 49-61.

Demir, I., Ertürk Ö., Nalçacioğlu R., Demirbağ, Z., 2000. Insecticidal effect some biological agents on the Gypsonoma dealbana (lepidoptera) and Hyphantria cunea. (lepidoptera) Pakistan Journal of Biological Science (3):552-554.

Dijerman, H. J., 1987. Notes on The Parasisation Behaviour and Larval Development of Complex rufinator and Diadegma armillata (Hymenoptera: Ichneumonidae), Endoparasitoids of The Genus Yponomeuta malinellus (Lepidoptera: Yponomeutidae) Proc. K. Ned. Akad. Wet. C (90): 271-280.

Driesche, R., Carey E ., 1987. Opportunities for Increased Use of Biological Control In Massachusetts. Res. Bull., Massachusetts Agricultural Experiment Station, 718/Oct. (1): 6-12.

Ecevit, O., 1988: Zirai Mücadele İlaçları ve Çevreye Olan Etkileri, Ondokuz Mayıs Üniversitesi Yayınları, Samsun.

Ertürk, Ö., 2007. Insecticidal Effects Of Selected Biological Control Agents On The Larvae Of Plutella xylostella (Lepidoptera: Plutellidae), Entomological Research, Volume, 37, Number 1

Erdem, F., 1979. Güney Anadolu Bölgesi'nde Elma Bahçelerinde Integre Mücadele Yönünden Böcek Faunası Üzerinde Ön Çalışmalar. Zir. Müc. Ar. Yıl 1 36-37.

Franck, H., and Genevieve P., 1997. Suitability of Yponomeuta malinellus and $Y$. cagnagellus (Lepidoptera: Yponomeutidae) as Host of Diadegma armillata (Hymenoptera: Ichneumonidae) Environ, Entomol,26 (4): 933-938.

Giray, H., 1969. Dursunbey İlçesi Çevresinde Bulunan Önemli Elma Zararlıları, Tanınmaları, Yayılışları, Konukçuları, kısa biyolojileri ve Zarar Şekilleri Üzerinde Illk Araştırmalar. E. Ü. Zir. Fak. Yayın No: (160): 49. 
Gottwald, R., Freier, B., Karg, W., 1986. Fundamentals of Integrated Plant Protection Against Animal Pest in High Intensity Apple Growing In The German Democratic Republic. NochrichtenblattFur Den Pflanzenschutz in Der DDR, 40,(1):1015.

Gürses, A., Atalay, M., Tüzün, Ş., 1985. Marmara Bölgesi Elma Zararlılarına Karşı Tüm (İntegre) Şavaş Olanakları Üzerinde Araştırmalar. Proje No: A107, 105 Yıllık Çalışma Programları (1974-1984), Böl. Zir. Müc. Ar. Enst., İstanbul.

İren, Z., Ahmed, M. K., 1973. Türkiye'nin Mikrolepidopterleri ve Meyve Zararlıları Bitki Koruma Bülteni,Ek Yayın (1): 69.

Jaques, R. P., Hardman, J. M., Laing J. E., Smith R. F., Bent, E., 1994. Orchardtrials in Canada on control of Cydia pomonella (Lep.:Tortricidae) by granulosis virus. Entomophaga (39):281-292.

Junnikala, E., 1960. Life History and Insect Enemies of Yponomeuta malinellus Zell. (Lepidoptera: hyponomeutidae) in Finland. Ann. Zool. Soc. Vanama(21): 3-44.

Kıroğlu, H., Aykaç, M. K., Çamlıdere, R., Ergünden, T. M., Çevik T., and Kılıç, M., 1984. Karadeniz Elma Bahçelerinde Tüm Savaş Olanakları Üzerinde Araştırmalar. Proje No: A-108.006, Yıllık Çalışma Raporları (19721983), Böl. Zir. Müc. Ar. Enst. Samsun.

Kuhlmann, U., Babendreier, D., Hoffmeister, T. S., Mills, N. J., 1998. Inpact and Oviposition Behaviour of Ageniaspis fuscicollis (Hymenoptera: Encyrtidae), a Polyembryonic Parasitoid of The Apple Ermine Moth, of Yponomeuta malinellus (Lepidoptera: Yponomeutidae). Bull. Entomol. Res.(88): 617-625.

Lipa, J. J., Wiland, E., 1972: Bacteria isolated from cutworms and their infectivity to Agrotis sp.,Acta Microbiologica Polonica, B (4):127140.

Lipa, J. J., 1975. An outline of Insect Pathology. Published for the U. S. Department of Agriculture and the National Science Foundation, Washington D. C., by the Foreign Scientific, Technical and Economic Information Warsaw, Poland.

Moar,W.J., Pusztzai-Carey, M, Mack, TP., 1995. Toxity of purified proteins and the HD-1 strain from Bacillus thuringiensis against Lesser Cornstalk Borer (Lepidoptera: Pyralidae). Journal of Economic Entomology 88: 606-609.
National Reserch Council, 1984. Subcommite on Insect-Pest, Insect-Pest Manegement and Control, Washington.

Oğuz, C., Karaçayır, H. 2009. Türkiye'de Elma Üretimi, Tüketimi, Pazar Yapısı ve Dış Ticareti.Tarım Bilimleri Araştırma Dergisi 2 (1):41-49.

Özçatalbaş O., Turhanoğulları, Z., Kutlar, I, 2009. Dünya Elma Üretim Sektörünün Genel Durumu ve Gelişmeler, Tarım Bilimleri Araştırma Dergisi 2 (1):139-144.

Peter, G. 1984. Plant Pests and Their Control, Fenemore, London.

Sezen, K., Demirbağ, Z., 1999. Bacteria İsolated from Balaninus nucum (Coleptera, Curculionidae) and Their Infectivity. Appl. Entomol. (34): 85-89.

Silvia D., 2001. Behavioural Ecolgy of Hyssopus pallidus, a Larval Parasitoid of The Codling MothCydia pomonella. Research Report Institute of Food Sciens, ETH WedJun, (1319): 33-33.

Tiryaki, O., Canhilal, R., Horuz, S., 2010. Tarım ilaçları kullanımı ve riskleri. Erciyes Üniversitesi Fen Bilimleri Enstitüsü Dergisi 26(2): 154-169.

Tayabali, A. F., Seligy, V. L., 2000. Human cell exposure assays of Bacillusthuringiensis commercial insecticides: Production of Bacillus cereus-like cytolytic effects from outgrowth of spores. Environmental Health Perspectives (108):919-930

Yaman, M., Sezen, K., Demirbağ, Z., 1999. Insecticidal effects of some biological agents on the larvae of Balaninus nucum (Coleoptera: Curculionidae) and Euproctis chrysorrhoea (Lepidoptera: Lymantriidae). Pak. J. Bio. Sci., (2): 617-618.Yiğit, A. ve Uygun, N., 1982: Adana içel ve Kahramanmaraş illeri Elma Bahçelerinde Zararlı ve Yararlı Faunanın Saptanması Üzerinde Çalışmalar. Bit. Kor. Bült., 22 (4): 163-177. 